\title{
Social Skills and Medical Youth of Ukraine: a Leadership Overview
}

\author{
Lesya Lymar \\ Institute of Postgraduate Training \\ O.Bogomolets National medical University \\ Peremohy Ave.34, 02000 Kyiv \\ Ukraine \\ e-mail: lesyalymar@ukr.net \\ Serhii Sova \\ Medical faculty No. 2 \\ O.Bogomolets National medical University \\ Peremohy Ave.34, 02000 Kyiv \\ Ukraine \\ e-mail: owls@ukr.net \\ Oleksandra Starodubska \\ Medical Faculty No. 2 \\ O.Bogomolets National medical University \\ Peremohy Ave.34, 02000 Kyiv \\ Ukraine \\ e-mail: 0991992526@ukr.net
}

\begin{abstract}
The issue of the physician social skills is particularly important in the modern medical environment, particularly within the context of medical leadership. Unfortunately, it has been neglected by medical environment of Ukraine for many years, due to existing social stigma and methods of managing the Ministry of Health. Nowadays the theme is becoming actual, especially with regard to the concept of leadership, even though little educational activities are dedicated to the issue.

Social skills of a physician should be defined within the context of his social competence, representing practical skills of interaction in the medical environment, and it mostly refers "physician "patient" interaction. The most "active" layers of the population is the youth, so youth awareness of the problem, particularly of medical youth, could change attitude of the society. The authors suggested on low awareness of the medical youth on the theme and conducted a survey with the $1^{\text {st }}$ and $2^{\text {nd }}$ year medical students of the $2^{\text {nd }}$ Medical faculty of Bogomolets National medical university, situated in the capital of Ukraine and best representing attitude of youth to the problem. The findings confirmed low awareness of the "physician social skills" problem and low level of expression of social skills in the freshmen, though some components of the issue are included into the medical curriculum. The authors suggest the necessity of education, both on the level of medical Universities and mass media, for increasing awareness of the problem and helping medical students and practicing staff to acquire the missing skills.
\end{abstract}

\section{Introduction}

The issue of physician's social skills should be considered within his professional competence. Starting with 1965 article of Derbyshire on medical competence (Derbyshire 1965), the issue of the physician professional competence has been widely studied by various authors (Bryl et al. 2012; Koenig et al. 2013), though it was neglected by the Soviet authors and, after 1991, by the authors from all the post-Soviet countries. Guerrero (2012) defines professional competence as the set of characteristics and skills that allow a person to develop his professional role. Literature review showed that most authors establish three basic components of the physician's professional competence: cognition(his knowledge), management( ability to organize his work, this also includes skills of medical work) and social, which includes interaction with patients and other participants of the medical environment, which is sometimes crucial (Seagull 1981; Ventres 2014). Matczak (2007), Nezu (2006), Lymar (2018) speak about social competence, social intellect and social skills of a physician, sometimes combining these three notions into the one whole. Loignon (Loignon et al. 2010) and Reinmann (Reinmann et al. 2004) studied social competence of physicians working with poor and outcasts, Bryl - general effect of physician's social competence, Kinman (2010) studied social competence of exactly social workers, Kiessling (Kiessling et al. 2010) paid attention to teaching social skills to medical students in Germany. 
Social competence could be defined as knowledge, abilities and skills of productive social performanceinteraction of a physician in the medical environment, while social skills is a little restricted notion, referring only to practical realization of the competence. Anyway, it's insufficient to know how a physician should interact, it is important how she or he interacts, and this is what the notion of social skills is about.

The notion of social skills is relatively new for Ukraine, as for one of the countries which "inherited" Health Service system from the Soviet Union, as the system hasn't been completely reformed even by 2019...The authors strongly believe that lack of social skills in all branches of public service deals with general ethical policy in the country, as such notions as discrimination, equality, partnership in relations have only recently entered Ukrainian ethical environment. As for medicine, the issue of medical personnel social skills isn't now a priority for the Ministry of Health of Ukraine, as analysis of most document showed lack of information on the subject. Medical universities "pay more attention" in their curriculum to fundamental theoretical and practical subjects, but not to ethical peculiarities of the physician-patient relations. Vast majority of the "old generation" tutors also don't provide for stressing the importance of social skills before the medical students, and these is the medical youth who will soon determine the "rules" in the Ukrainian Healthcare market within next years. That's why the issue of the medical youth awareness of the theme has deeply interested the authors and prompted to study this problem.

\section{Methods}

Basing on the literature review and personal experience of tutorship and dealing with the students within the Dean's Office in Medical University, the authors suggested that the notion of "social skills of a physician" hasn't been widely recognized by medical students. In order to confirm this suggestion, the authors held a study with the students of the $2^{\text {nd }}$ Medical Faculty of National medical university named after Bogomolets (Kyiv, Ukraine). The study engaged 168 students of the first and second study years ( 86 of the first and 82 of the second, 126 females and 42 males). The study was held in winter of 2018-2019 academic year, the participation was free, upon obtaining students' oral consent.

The students were offered 6 questions, the last one being subdivided into 10 sub-questions. Firstly, the students were asked to define their knowledge about the physician's social skills choosing the most suitable answer: "I definitely know what they are". "I probably know what they are", "I probably don't know what they are" and "I haven't heard about this". The students were also asked to answer if social skills are important for the physicians, choosing the most preferred answer as: "Very important", "More important than not important", "More unimportant than important" and "Absolutely unimportant". The students were also asked if they knew anything about conflict interaction styles ( asking further to name them) and communicative mindset, choosing the most appropriate answers: "I definitely know about this", "I probably know more than don't know about this", "I probably more don't know than know about this" and "I don't know about this". Then the students were asked to tell if they heard about "physician's social skills" from their University teachers, choosing the most appropriate answers from the following: "We were often told about this notion by University teachers", "We were sometimes told about this notion by University teachers", "We were once or twice told about this by university teachers" and "We were never told about this notion by our university teachers". The students were also asked if they would treat equally all their patients, including: wealthy calm patient, old grumbling woman, homeless child taken from the street and a well-educated middle-aged woman, with the offered answers: "I definitely will treat them all equally", "I will treat them a little bit unequally", "I will definitely treat them unequally". Another question referred to the conflict interaction of a patient and a physician, where the students were offered 10 medical cases of "hard, conflict interaction", being asked to choose the preferred interaction style: cooperation, adjustment, avoiding, confronting, compromise. The obtained data were statistically processed with Statistica SPSS software. To estimate the reliability of findings, the Student t-criterion was applied.

\section{Discussion}

We intentionally surveyed only students of the $1^{\text {st }}-2^{\text {nd }}$ study years, who haven't been on practical classes in hospital wards (starting with the $3^{\text {rd }}$ study year in Ukraine), as the answers of this group best represent attitude of the students and theoretical subject tutors to the social skills issue. It is important to note, that further practice and experience of interaction with the patients during practical classes could substantially change the obtained results. The findings evidence about poor understanding of the theme by Ukrainian students.

Table 1. Student knowledge of the notion "Physician's social skills"

\begin{tabular}{|l|c|c|c|c|}
\hline & $\begin{array}{c}\text { "I definitely know } \\
\text { what they are", } \%\end{array}$ & $\begin{array}{c}\text { "I probably know } \\
\text { what they are", } \%\end{array}$ & $\begin{array}{c}\text { "I probably don't } \\
\text { know about this", \% }\end{array}$ & $\begin{array}{c}\text { "I don't know } \\
\text { about this", } \%\end{array}$ \\
\hline All students & $9.5 \%$ & $39.3 \%$ & $37 \%$ & $14.2 \%$ \\
\hline
\end{tabular}

Source: Own results 
As Table 1 shows, almost the same number of the surveyed confirmed that they met and didn't meet with the social skills notion, with those who "didn't know" prevailing over those who "knew"( 14.2\% against 9.5\%), and the same trend is traced with those who chose the "probably" answer, which expressed uncertainty have met and haven't met with the notion $(p<0.05)$.

We consider these findings to be indicative of low awareness of the problem, as only $9.5 \%$ confirmed that they knew about the issue, which only showed their attitude, but did not confirm the fact of knowledge.

Table 2. Ranging the physician's social skills importance

\begin{tabular}{|l|l|l|l|c|}
\hline & "Very important", \% & $\begin{array}{c}\text { "More important than } \\
\text { not important", \%. }\end{array}$ & $\begin{array}{c}\text { "More unimportant } \\
\text { than important", \%. }\end{array}$ & $\begin{array}{c}\text { "Absolutely } \\
\text { unimportant", \% }\end{array}$ \\
\hline All students & $9.1 \%$ & $28.3 \%$ & $33.7 \%$ & $28.9 \%$ \\
\hline
\end{tabular}

Table 2 shows almost similar trend observed when analyzing the importance of this notion for medical student, which more definitely expresses their attitude, not awareness of the problem. While the students were offered to range the physician's social skills importance for them, related to medical activity, the majority ranged it as "more unimportant than important", with $33.7 \%$ against $9.1 \%$ who really paid attention to the issue $(p<0.05)$. The group of those who consider "physician's social skills" absolutely unimportant here significantly prevails over those who considered it "very important", being almost equal to those who suppose it to be "more important than unimportant", but, anyway, without definite motivation. This, up to the authors' mind, means poor educative activity targeted at physician social skills importance, conducted both by mass media with the environment and university teachers. The so-called "unsure" group represents the majority of Ukrainian first-year students: probably-knowing-something about social skills of a physicians and probably-considering-it-somewhat-imortnator-unimportant.

To confirm this, we analyzed student awareness of the topic as for being told by their university teachers, with the following findings shown in table 3.

Table 3. Student awareness of the "physician social skills" from University tutors

\begin{tabular}{|l|c|c|c|c|}
\hline & $\begin{array}{c}\text { "Often told by } \\
\text { teachers", } \%\end{array}$ & $\begin{array}{c}\text { "Sometimes told by } \\
\text { teachers", } \%\end{array}$ & $\begin{array}{c}\text { "Once or twice told } \\
\text { by teachers", } \%\end{array}$ & $\begin{array}{c}\text { Never told by } \\
\text { teachers", } \%\end{array}$ \\
\hline All students & $21.9 \%$ & $48.4 \%$ & $26.4 \%$ & $3.3 \%$ \\
\hline
\end{tabular}

Source: Own results

The majority of the respondents were sometimes told by their tutors about the issue, and this is not surprising, as the first and second year medical students in Ukraine study various deontologically based subjects, like "History of medicine", "Psychology(with subcourse "Psychology of patient", "Philosophy (with medical subset), and an elective course "Deontology", not even to mention that all tutors of theoretical departments (anatomy, histology, physiology classes) aim their subject to be practically based, with numerous examples of doctor-patient interaction. Though, only $21.9 \%$ state that they were often told about the issue by their teachers, as the "sometimes told" or "once or twice told" answers were chosen more often $(p<0.05)$. Here we again meet with unsure pattern of physician social skills shaped in the students. Unfortunately, factor analysis didn't give reliable groups.

To check if the students really knew about components of social skills, they were asked to range their knowledge on conflict interaction style (and name the known styles) and communicative mindset. The answers where the students confirmed their knowledge of the styles, but couldn't name them, were considered equal to "I don't know" answers. If the students could name correctly conflict interaction styles, we considered his own estimation of his knowledge to be true. The results showed that total majority doesn't have any notion on psychological basis of productive interaction, despite the studied subjects. Almost the same amount could relatively confirm their knowledge and state insufficient apprehension of the issue, which is shown in Table 4.

Table 4. Student knowledge on conflict interaction styles and communicative mindset

\begin{tabular}{|c|c|c|c|c|}
\hline & $\begin{array}{c}\text { "I definitely know } \\
\text { about this", } \%\end{array}$ & $\begin{array}{c}\text { "I probably know } \\
\text { more than don't know } \\
\text { about this", \% }\end{array}$ & $\begin{array}{c}\text { "I probably more } \\
\text { don't know than know } \\
\text { about this", \% }\end{array}$ & $\begin{array}{c}\text { "I don't know } \\
\text { about this", } \%\end{array}$ \\
\hline $\begin{array}{c}\text { All } \\
\text { respondents }\end{array}$ & $4.6 \%$ & $14.4 \%$ & 17.3 & $62.7 \%$ \\
\hline
\end{tabular}

Source: Own results 
It is interesting to compare these findings, with $4.6 \%$ knowing about interaction, $62.7 \%$ showing no apprehension of the issue and $31.4 \%$ of the "so-so" knowing the issue students to $9.5 \%$ of those who in the first questionnaire assumed that they "definitely knew" about social skills, $78.3 \%$ of the "so-so" aware or unaware of the problem and $14.2 \%$ of totally unaware of the problem. So, totally, more than $60 \%$ of all respondent state that they don't know about physician social skills and confirm this loss of knowledge in practice.

To check for the student attitude to different social layers and to find the interrelation between the knowledge and practical application of social skills, the students were asked if they would equally treat patients from various social groups. As for the cases with "hard physician-patient" interaction, most students chose the confrontation ( $23.1 \%$ ), avoiding ( $19.1 \%$ ) and adjustment $(17.5 \%)$, with cooperation taking only $5.6 \%$ of all respondents, which may be explained by low communicative culture of the students, "explosive" late teenager period experienced by the freshmen and high level of social strain in the Ukrainian society (which was recently confirmed by presidential elections) $(p<0.05)$. So, this also evidences about low social skills level expressed by the respondents.

Table 5. Equality of treatment expressed by medical students

\begin{tabular}{|c|c|c|c|}
\hline & Definitely equal, $\%$ & A little bit unequal, $\%$ & Definitely unequally, $\%$ \\
\hline All respondents & 42.05 & $48.15 \%$ & $9.8 \%$ \\
\hline
\end{tabular}

Source: Own results

Table 5 shows the findings of the survey when the students were asked if they would treat patients from various social groups equally. And here low social skills level expressed by the students was confirmed once more, as the majority of the students said they would treat different patients unequally, as if considering that "a little bit"" isn't counted for violation of the physician's Code, and only 42.05 answered about total equality. But, up to the authors' mind, this is more related to positive self-image and unwillingness of the surveyed to confirm that they may be subjective and deny certain patients their right for help, as these findings don't correlate with any of the previous ones.

Thence, having analyzed the findings, it is possible to conclude on very lower level of medical student awareness of the physician social competence theme. The respondents express their opinions with prevailing uncertainty: "I probably know or don't know" or "I was sometimes told about it". Generally, the freshmen show little knowledge on the issue of physician social skills, their structure, importance of these skills in medical practice and low possibility of application of the social skills while interacting with the patient, despite this issue has been taught at theory and practice subjects during first two years. The second, they didn't even pay significant attention to the problem. Combined with low level of the shaped social skills, this produced rather poor prospective. Considering this, the necessity of re-structuring medical university curriculum as well as conducting education activities with the mass media sector referring to the social competence, particularly of physicians, seems to be quite important. The last is regarded as the necessary component of education conducted by the teacher staff and Dean Office of the faculty.

\section{Conclusions}

Social skills of a physician represent a component of the physician social competence, showing the abilities and skills of practical application of the present knowledge. The issue of physician social skills is insufficiently highlighted by mass media and various departments of Ministry of Health of Ukraine, which is evidenced by literature review.

The conducted survey of the $1^{\text {st }}-2^{\text {nd }}$ year medical students of the $2^{\text {nd }}$ Medical Faculty of O.Bogomolets National medical university evidences about low awareness of the problem, absent theoretical knowledge of "what the physician social skills are" and their importance in professional activity, low level of personal social skills of the surveyed as well as low readiness to apply them while interacting with the patients.

All this requires for measures taken by Ministry of Health of Ukraine and medical institutions in order to increase the population awareness of the problem, particularly referring to practicing physicians and medical students.

\section{References}

Bryl N, Horst-Sikorska W, Ignaszak-Szczepaniak M, Marcinkowska M, Michalak M, Sewerynek E (2012) Influence of social competence of physicians on patient compliance with osteoporosis medications-a study on Polish postmenopausal women. Polish gynecology 83 (7):511-516. 
Derbyshire RC (1965) What should the profession do about the incompetent physician? JAMA 194 (12):12871290. doi: 10.1001/jama.1965.03090250021004

D'Zurilla TJ, Nezu AM, Problem-solving therapy. Handbook of cognitive-behavioral therapies, $3^{\text {rd }}$ edn. (Guilford Press: NY, U.S, 2010), pp. 197-226

Guerrero D, De los Ríos I (2012) Professional competences: a classification of international models. ProcediaSocial and Behavioral Sciences 46: 1290-1296. doi: 10.1016/j.sbspro.2012.05.290

Kiessling C, Dieterich A, Fabry G, Hölzer H, Langewitz W, Mühlinghaus I (2010) Communication and social competencies in medical education in German-speaking countries: The Basel Consensus Statementю Results of a Delphi Survey. Patient Education and Counseling 81 (2):259-266. doi: 10.1016/j.pec.2010.01.017

Kinman G, Grant L (2010) Exploring stress resilience in trainee social workers: The role of emotional and social competencies. The British Journal of Social Work 41 (2):261-275. doi: 10.1093/bjsw/bcq088

Koenig TW, Parrish SK, Terregino CA, Williams JP, Dunleavy DM, Volsch J M (2013) Core personal competencies important to entering students' success in medical school: what are they and how could they be assessed early in the admission process? Academic Medicine 88 (5): 603-613. doi: 10.1097/acm.0b013e31828b3389

Loignon C, Haggerty JL, Fortin M, Bedos CP, Allen D, Barbeau D (2010) Physicians' social competence in the provision of care to persons living in poverty: research protocol. BMC health services research 10 (1): 79 . doi: 10.1186/1472-6963-10-79

Lymar L, Omelchuk S (2018) Factors of the medical career choice within the context of ukrainian healthcare reforms. Wiadomosci lekarskie 71 (2): 211-216. doi: 10.7256/1339-3057.2013.1.9478

Matczak A (2007) Kwestionariusz kompetencji społecznych, Pracownia Testów Psychologicznych Polskiego Towarzystwa Psychologicznego.

Reinmann JO, Talavera, GA, Salmon M, Nuñez, JA, Velasquez RJ (2004) Cultural competence among physicians treating Mexican Americans who have diabetes: A structural model. Social Science \& Medicine 59 (11): 2195 2205. doi: 10.1016/j.socscimed.2004.03.025

Seagull A, Barker WH, Cobb S, Jackson G, Noren J, Shindell S (1981) Development of a competency-based approach to teaching preventive medicine. Preventive medicine 10 (6): 726-735. doi:10.1016/00917435(81)90038-4

Ventres WB (2014) Becoming a Doctor: One Physician's Journey Beyond Competence. Journal of graduate medical education 6 (4):631-633. doi:10.4300/jgme-d-14-00144.1 